

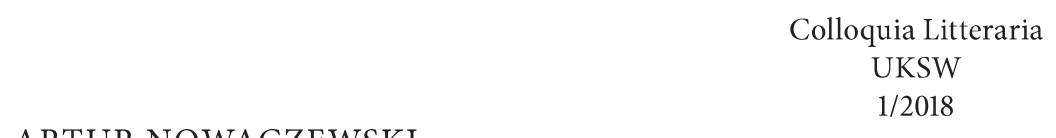

ARTUR NOWACZEWSKI

\title{
THE MESSAGE OF THE CASTAWAY: ORPHIC THEMES IN THE POETRY OF KRZYSZTOF KARASEK
}

\author{
In every generation/there are those who/with \\ stubbornness worthy of a better cause/wish to rip \\ poetry/from the claws of/everyday \\ Zbigniew Herbert, "Mr. Cogito. Ars longa"1
}

Zbigniew Herbert wrote three poems in which three poets of "Nowa Fala" ("The New Wave") are referred to by name. "Do Ryszarda Krynickiego-list” (“To Ryszard Krynicki-a Letter”), "Widokówka od Adama Zagajewskiego ("The Postcard from Adam Zagajewski”), and a poem dedicated to Krzysztof Karasek "Pan Cogito. Ars Longa" ("Mr. Cogito. Ars Longa"). Even the very titles show Zbigniew Herbert's specific sense of humour-one sends letters to Ryszard Krynicki, receives postcards from Adam Zagajewski and discuses things permanent in art, as well as ironically comments on the transience of hierarchies in literary life with Krzysztof Karasek.

Herbert's opinion about Karasek is well known and often repeated: he considered Karasek to be the best poet of the New Wave generation. "His poetry is mature, serious, intellectually profound and very well 'made' in literary terms. Using sporting jargon he has one with his

1 Zbigniew Herbert, Collected Poems 1956-1998, transl. by Alissa Valles, Harper Collins, New York, 2007. 
generational colleagues by the whole length of a boat." Tomasz Burek is also a great admirer of Karasek who, while humorously comparing two group of poets: the Skamander poets and the New Wave poets, equalled Karasek's role in poetry to that of Jarosław Iwaszkiewicz. ${ }^{3}$ Yet, Karasek is non-existent in a wider reception which goes beyond the circle of poets. Of course, this has happened to many contemporary authors, but it is difficult to find a poet whose output is so important artistically and intellectually, and who has received so little attention in the world of Academia. Karasek is an almost totally unresearched poet, and his output is to a large extent terra incognita. One may, of course, ask questions about why it is so, or deal with mechanisms of literary life in Poland after 1989. It is worth talking about Karasek's poetry from the perspective of the history of literature.

This is a difficult task, because in the second half of the twentieth century just a few schemata were used, according to which literary hierarchies of this period were formed. One of the categories used at that time was that of the generation. The success of a generation, which was ingested by literary scholars, may, paradoxically, adversely affect the reception of the individual writers who formed it. This is so because their output gets limited by the frames constructed in their youth, limited by the programme of the group of young writers. And, yet, after all, the process of the development of a writer does not end at the debut and the establishing of one's position among colleagues, but enters the decisive phase exactly at the moment when an author finds the thing which distinguishes him from his colleagues and finds his unique voice.

Karasek worked hard and achieved this voice, which has been heard over the last quarter of a century with surprising intensity. During that time he published seventeen volumes of poetry (before 1989 he had published only six).

\footnotetext{
${ }^{2}$ See Zbigniew Herbert, Polecam - odradzam, in Idem, t Węzeł gordyjski oraz inne pisma rozproszone 1948-1998, ed. by Paweł Kądziela. Warszawa 2001. Herbert recommended Karasek's volume of poetry Czerwone jabłuszko. (A Litlle Red Apple).

${ }^{3}$ See Tomasz Burek, Dzieło niczyje, Kraków 2001, 30-49.
} 
A poet may be present in the history of literature in different ways: in the canon of texts to be read, in the reception of literary critics and academics, through his own biographical legend and, finally, in the web of intertextual references, through which he appears in the works of other writers. This last form of presence is the result of the fact that no writers write in total isolation; a poet either 'invites' other writers into his own poetic world-through dedications, allusions, referencesor, in a similar way, he is 'invited' into the writings of other poets and is present in this way. So, we have a permanent dialogue going on with tradition, with contemporaries and generations to come. This sort of presence is typical of Krzysztof Karasek, who dedicated many poems to his fellow poets and who equally often received such dedications. It was not only masters like Zbigniew Herbert who devoted poems to him, not only his contemporaries and generational friends (Julian Kornhauser), but also disciples, fans and friends from younger generations. Karasek is appreciated by a surprisingly wide range of communities: by poets centred around "Nowa Okolica Poetów” (New Poets' Neighbourhood”) from Rzeszów, “Topos” from Sopot, and Instytut Mikołowski (Mikołowski Institute). Karasek drew young artists towards himself not only through the strength of his poetry, but also through his charismatic, colourful personality.

Karasek's poetry is extremely erudite. His cultural education was really impressive, and it covered literature, philosophy, painting, classical music, history and sport. And he was an amateur in all these disciplines (if we disregard the fact that he graduated from the Academy of Physical Education and jumped with a pole vault). He is a Humanist of a format extremely rare these days. His works, when compared with the works of other poets, turned out to be very varied in tone-from serious erudite long poems with philosophical musings, to humorous poems, light and epigrammatic. In times when literary non-fiction and autobiographical non-fiction are so highly esteemed, what becomes important is not only the reading of texts, but also experiencing literature through contact with distinguished writers. Karasek knew a lot of the great people of his period and was a friend of some of them. The measure of their greatness was, 
among other things, brilliance during personal contacts; Karasek watched his masters and colleagues in different situations and drew conclusions from these observations; the measure of personal life is not the ultimate criterion of an artist, but it should not be excluded either.

For over twenty years Karasek's poems were held together by the figure of the protagonist. Karasek used the term 'castaway' to describe this lyric 'I'. As a result, we have a picture of the world after a disaster, a distance towards himself, lack of illusions, but also praise of life.

And finally-and this feature is most important for Karasekpoetry is his main cognitive tool. It is true, he philosophises, he has a unique painterly and musical sensitivity, he is an erudite; but all this is subjected to poetry. The poem is the ultimate measure of things, while writing is something indispensable to be fully human. This stress on his being a poet seems to be almost annoying these days, yes, almost 'outdated', as a gesture of independence from fashions, trends and social expectations (or rather social indifference).

The castaway lives in a world in which the marginalization of poetry is a fact, but he accepts it as something natural. His writing is not a lament for the decline of culture. In Karasek's writings imagination is enlivened by culture, but culture is also enlivened by imagination. However, imagination has one distinct advantage. You can learn culture, you can acquire it, you might even be soaked up by it-while imagination is inborn, the source of the pictures it offers is not always clear. It is difficult to be a poet without culture, but it is possible. You cannot be a poet without imagination.

The castaway is the most important of Karasek's figures. How can it be defined? Karasek himself did it most fully in the afterword to the second part of Dziennik Rozbitka (The Castaway's Journal). He explains there what differentiates his protagonists from the subjects created by poet-catastrophists. A castaway is not a loser; it is not someone, who, like catastrophists, awaits a catastrophe, and gets ready for it: 
A. NOWACZEWSKI, “THE MESSAGE OF THE CASTAWAY...”

\begin{abstract}
A castaway is someone after a catastrophe, who survived it and became stronger as a result. A catastrophe of faith. A catastrophe of love. A catastrophe of the body's decay, and all others [...]Someone who lives after the catastrophe and does not consider it unusual. $\mathrm{He}$ thinks that this fact is an inherited necessity, and even certainty with which he must live, similar to Original Sin; he must learn to live with it. The castaway does not turn the catastrophe into a fetish, as catastrophists do. He believes that his life after the catastrophe is fuller, truer; a full dimension of humanity appears only after the catastrophe. And in this intuition he is closer to Dostoyevsky, for whom the fall is part of man's condition, part of his life on earth, and Providence testing him - through this fall-gives him a unique opportunity to take matters into his own hands and influence his destiny. ${ }^{4}$
\end{abstract}

The poet presents a line of castaway figures: the Biblical Adam, the mythical Orpheus, Klabautermann from "The Flying Dutchman", Moby Dick's key protagonist Captain Ahab, the protagonist from Adam Mickiewicz's sonnet "Burza" ("The Tempest"), the protagonist from Coleridge's "Rime of the Ancient Mariner", or Dostoyevsky's Raskolnikov.

Orpheus's place in this gallery is unusual. Of course, going back to an Orphic myth is nothing new. It has been done in different periods. Romantics gave it a particular meaning. Maria Janion, in Gorączka romantyczna (Romantic Fever), wrote about two types of Romanticism-originated by Orpheus and Tyrtaues. Orphic Romanticism was based on the soul's descent into the depths of a mystic soul; the one originated by Tyrtaues into depths of history. But, what is important is that both types stressed the necessity of learning about oneself during wanderings or a pilgrimage. ${ }^{5}$ Orpheus

\footnotetext{
${ }^{4}$ Krzysztof Karasek, Dziennik rozbitka II, Sopot 2004, . 50.

5 Cf., Maria Janion, Czas formy otwartej. Tematy i media romantyczne, Warszawa 1984,14 . The discovery of the Orphic Romanticism happened, according to Janion, in the period of Young Poland, See Maria Janion, Gorączka romantyczna, Warszawa 1975, 166.
} 
was connected with inspired poetry. Romantics were interested in various aspects of the Orphic myth-the journey of the Argonauts, love between Orpheus and Eurydice, initiation in the mystery, the magic powers of Orpheus' poetry, his death. Orpheus united in his person the cults of two antagonistic gods: Apollo and Dionysus: "...he is also a mediator between the living and the dead; he embodies a Romantic idea of the return to primordial oneness, the connecting of things separated, in all possible dimensions: material and spiritual, earthly and cosmic realities". ${ }^{6}$ Orphic motives appear in the texts of Kazimierz Wierzyński, Konstanty Ildefons Gałczyński, Stanisław Baliński, Aleksander Wat, Adam Ważyk, Roman Brandstaetterand Jan Bolesław Ożóg. ${ }^{7}$

Orpheus was also referred to in many twentieth-century essays. Józef Wittlin presented him in the context of World War II, from the perspective of concentration camps. He pointed to the powerlessness of poetry against totalitarianism, its lack of any real power, marginalization being a result of civilization's progress. He also stressed the separation of poetry and music, which deprived poetry of its primordial powers. It results in the situation when the condition of a poet in the contemporary world must be defined differently than was the case with the ancient model:

The mythical Orpheus tamed wild beasts with his songs, so that they gathered at his feet [...] Today Orpheus has no such power. He cannot even tame a wild beast locked in the cage of the human heart.[...] The hell of the mythical Orpheus was underground. It was Hades, where the dead lived. The hell of the Orpheuses of todayah, we know it only too well-is the earth inhabited by living men. Our Orpheuses, poets without lyres and musicians without power, sometimes also tear hearts from the hell in which we live. But their

\footnotetext{
${ }^{6}$ See Magdalena Siwiec, Orfeusz romantyków. Mit o Orfeuszu w twórczości Juliusza Słowackiego i Gerarda de Nerval w kontekście epoki, Kraków 2002, 131.

7 Cf. Stanisław Stabryła, Hellada i Roma w Polsce Ludowej. Recepcja antyku w literaturze polskiej w latach 1945-1975, Kraków 1983; Stanisław Stabryła, Hellada i Roma. Recepcja antyku w literaturze polskiej w latach 1976-199o, Kraków 1996.
} 
A. NOWACZEWSKI, "THE MESSAGE OF THE CASTAWAY...”

voice is too weak to deafen the killing noise of earthly life, the hellish roar of murderous machines. Today Orpheus must outshout, even in peacetime, the horrible hell of artificial, man-made sounds. ${ }^{8}$

Zbigniew Bieńkowski, in "Piekła i Orfeusze" ("Hells and Orhpeuses"), wrote about the two wings of contemporary literature "the light one and the black one", which have Lev Tolstoy and Fyodor Dostoyevsky as their patrons. "The black wing" is to open the road to hells, and Bieńkowski placed Kafka, Joyce and Faulkner within it. They explore 'humanity's underground'; they struggle with themselves, with what is inside them. ${ }^{9}$ The concepts of both writers-Wittlin and Bieńkowski-are to a large extent, similar. They select the descent to hell out of the Orphic myth, while they extend its meaning-it is not a hell from Dante, but also underground in the sense in which Dostoyevsky used it, of our internal hell.

For Karasek Orpheus is a unique figure because he combines features of a castaway and a poet. What is crucial is that Karasek's reinterpretation of the Orphic myth is connected with the change of poets' status in the contemporary world (among other things, after 'the death of poetry' announced by Tadeusz Różewicz). The figure of the castaway should be put alongside that of Różewicz's rescued one. In both cases the protagonists have to find their place in life after catastrophes. However, there also exist distinct differences between them. Różewicz's protagonist is a young man, who experienced war, saw the fall of humanity, the defeat of morality in the context of the reality of concentration camps, and the defeat of culture. He experiences a situation in which the world of values has been turned into a ruin; in which good and evil are indistinguishable. So he looks for 'a guide and a master'. The castaway's catastrophe (in Karasek's writings) happens in a different period of life-it happens to a mature man during a mid-life crisis. He is no longer looking for a master; he must become one for himself. We can see traces of existentialist

\footnotetext{
${ }^{8}$ Józef Wittlin, Orfeusz w piekle XX wieku, Kraków 20oo, 428.

9 See Zbigniew Bieńkowski, Piekła i Orfeusze. Szkice z literatury zachodniej, Warszawa 2009, 47-49.
} 
philosophy here, the philosophy Karasek was so close to when he was young. According to its assumptions, existence comes before essence-man, in order to define himself, needs first to 'happen', to gather experiences, which are necessary for man to find himself. This 'rescued one', therefore, although he lives after the catastrophe, still experiences it-the catastrophe remains with him like a wound which will not heal, while the castaway has already accepted this condition and has managed to treat his defeat in a detached way.

In Karasek's poetry written after 1989 Orphic motives appear many times. ${ }^{10}$ They had also been present earlier. In the volume Prywatna historia ludzkości (A Private History of Humanity) (1979) there is a text of poetic prose entitled "Orfeusz w barze mlecznym" ("Orpheus in the Diner"). There, Karasek contrasted the mythological motif with trivialities of the contemporary life. In the poem from 1987 called "Orfeusz" ("Orpheus') Karasek still used poetics similar to that of his master, Zbigniew Herbert; we can discern here traces from "Apollo i Marsjasz" ("Apollo and Marsyas"): "A poet is tuning instruments", "letters ring, buzzes the head's lute", "the body's violin is extinguished". Herbert described Marsyas's body being torn apart in a similar way. In both poems (by Herbert and Karasek) we have descriptions combining physiology with music. In the 1990s Karasek conversed with Herbert on equal terms. The Castaway's Journal includes a poem entitled "Rady dla Orfeusza" ("Advice for Orpheus"), which may be treated as a key, a 'programme' poem, in the same way as Herbert's "Przesłanie Pana Cogito" ("The Message of Mr. Cogito") is a 'programme poem'. It is worth quoting the whole poem:

\footnotetext{
10 See. Rady dla Orfeusza, in Dziennik rozbitka, Mikołów 2012; Z objawień orfickich, in Dziennik rozbitka II, op. cit.; Gondwana, in Gondwana i inne wiersze, Warszawa 2006; Tryptyk orficki, in Gry weneckie, Sopot 2007; Orfickie oraz Orfeus redivivus, w: Wiatrołomy, Sopot 2011; Ukąszenie orfickie a życie w realu, in Słoneczna balia dziecinstwa, Sopot 2013. Quotations from poems come from these editions.
} 


\section{Rady dla Orfeusza (Advice for Orpheus)}

Światło objawia gramatykę cienia, ciemność obnaża logikę poznania, wiara odsyła nas do przeszłości. Widzimy niejasno, w pomieszaniu, czas załamuje się, a przestrzeń tężeje, to co widzialne rodzi niewidzialne, co niewidzialne otwiera równinę po której kroczą Szekspir i Rimbaud. Więc nie oglądaj się za siebie, światło jest ciemnym deszczem, który piją zmarli, nie mów, że nie wiedziałeś. Ludzie oniemieli od tej wiedzy, z którą wszyscy, sami musimy żyć. Światło jest kroplą, zlizuje je spod powiek poranny śnieg podczas gdy horyzont, jak linia w ręku malarza się wygina. Twoim jest powietrze, niepamięć i zdumienie. I jeszcze chwila, gdy mija. Była, więc jest. Odżywiaj się nią lecz nie patrz, nie spoglądaj za siebie, to ona właśnie cię pożre gdy się w nią wbrew mitom zapatrzysz. Idź

gdzie syreny wiodą swój miodny śpiew, miej oczy zwrócone ku świętym ołtarzom, nie drżyj gdy nieprawości całują cię wargi. Patrz uważnie, aż do najokrutniejszej wiedzy, niech niesie cię jak echo nieboskłon, jego blask

mroźnym światłem jutrzenki osmali ci twarz. ${ }^{11}$

11 "Light reveals the grammar of shadows, darkness denudes/the logic of cognition, faith sends us back to the past/We see indistinctly, in confusion, time breaks/ apart, while space solidifies, that which is seen/bears the unseen, what is unseen opens a plain on/which tread Shakespeare and Rimbaud/So, do not look back,/ light is a dark rain which the dead drink,/don't tell me, you didn't know, People are boggled/with this knowledge, with which we all/have to live. Light/is a drop, it gets licked/by morning snow/while the horizon bends like a line/in a painter's 
The resonance of the poems-Herbert's "The Message of Mr. Cogito" and Karasek's "Advice for Orpheus"-is, in many ways, similar. Putting them alongside seems to be appropriate as they both refer us to the myth of Orpheus. After all, in Herbert's poem we have "the golden fleece of nothingness", sending us straight into the journey of the Argonauts, in which Orpheus played a meaningful role.

Both Herbert and Karasek write after a catastrophe. It may be seen as a catastrophe of European culture and faith, as well as the catastrophes of their protagonists-on different planes: personal, existential and meta-poetic. However, while "The Message of Mr. Cogito" refers to the tradition of Tyrtaues, adapts it to everyday life and postulates the stubborn heroism of the intellectual-inheritor, the guardian of old myths against the verdicts of history, in "Advice for Orpheus" we deal with different areas of experience, usually described in terms of the Orphic tradition. The importance of Mr. Cogito's message lies in the social impact of his attitude, of a citizen of a "boundless kingdom" and "a city of ashes", endangered by "spies, executioners and cowards". The message of Karasek's castaway is first of all personal, because we experience the key existential borderline situations alone. Karasek's Orpheus is also on the road, but this is a road which is just being experienced. Herbert's protagonist faces external reality and historical hell. Karasek's protagonist is, first of all, someone who overcomes his internal hell, who against all-encompassing depression enlivens his own will to live. While in Herbert's poem the light was distant-it gave signs in mountains, in Karasek's poem the experience of light is necessary for existence, for growth. This light has been described with the sensitivity of a painter. It is very important for the lyric 'I' to catch this moment and create an impression about it. In Herbert's

hand. Yours is air/oblivion and surprise. And a moment when it passes. It was/so it is. Feed on it/but don't look, don't look back, it will/devour you, when you stare into it against myths. Go/where sirens have their honey song/have your eyes turned towards holy altars, don't quake/when iniquities kiss your lips. Look/closely, till the cruellest of knowledge, let you be carried/by skies, its glare will char your face with the wintry light of dawn." 
A. NOWACZEWSKI, “THE MESSAGE OF THE CASTAWAY...”

poem the past is static, it is a constant point of reference, a rubbish heap of myths, out of which one can take "charms of mankind, fables, legends". In Karasek's poem the past is as dynamic as the present; it is real because it gives power to live. "Faith sends us to the past". The capital of personal experiences, all experiences, both good and bad, is wealth. Because the fullness of life is created by the dialectics of light and shadow. The past is also the background of imagination; the relation with the past is organic, almost sensual. According to myths, Orpheus's songs had an effect not only on men, but also on plants. They tamed animals, and could quiet waves. Waking up poetry in oneself and functioning as its medium has a therapeutic dimension."The Message of Mr. Cogitio" and "Advice for Orpheus" are complementary poems. But for the castaway the incentive to action is also the present, the ability to be surprised-and, differently than in the case of Herbert-the ability to forget, to get rid of the surplus of experiences. For Herbert the highest values were memory and awakening in oneself emotions from the past. Karasek is convinced that in order to live one cannot look back, because the past is written in us in a natural way. This was exactly Orhpeus's undoing: his looking back, his fear when he was leading Eurydice out of hell. This fear also, of course, exists in Karasek's poetry, but it is constantly conjured, tamed. Everything is done in order to take life stoically, to take it as it is. But Karasek's stoicism is not the extinguishing of emotions, it is not indifference; it is a balance of emotions reciprocally abolishing themselves. That is why "wintry light of dawn chars the face". In the autumn of life Karasek identifies himself with Orpheus. He writes in the poem "Z objawien orfickich" ("From Orphic Epiphanies"):

Nie wiedząc o tym zstąpiłem do podziemi.

Było jak nadziemie,

tylko światło było inne. Zstępujące.

[...]

Nie przypuszczałem, że to tak szybko się stanie,

myślałem.

Ledwie pogrzebałem swoich mistrzów

a sam stałem się mistrzem. 


\section{[...]}

Cienie niepocieszonego dziedzictwa

Świata przesuwały się obok mnie,

jakby otulone grubą warstwą mgły. ${ }^{12}$

Many people whom Karasek knew had died. Therefore he became, quicker than he expected, a middle man between the worlds of the living and of the dead, a depository of knowledge he acquired from his predecessors. Now it is the young who converse with him in the way he used to converse with his masters. A poet carries inside "a shadow of inconsolable heritage of the world". A poet lives, but his life is to a large extent already on the other side, underground.

In one of his poems Karasek uses the expression an "Orphic bite", which is, of course, based on the phrase "Hegel's bite". An "Orphic bite" protects the lyric "I" from Hegel, although Karasek when he was young, similarly to his peers from the New Wave, wrote poems, coping with the present, "the spirit of time"; committed poems. He, however, was soon to embark on his own way, which his peers could not understand. From this perspective, his poetic dialogue with Julian Kornhauser is very interesting. After reading Gondwana Kornhauser, in 2007 wrote a moving poem entitled "Do Krzysztofa Karaska" ("To Krzysztof Karasek"). The poem contains a portrait of Karasek. Kornhauser presents a young man bitten by poetry.

Kiedy zapadasz w sen razem z kwidzyńskim niebem spod kożucha, zapala mi się światło naszej młodości, której nikt nie chciał strzec. Twoje w tamtym czasie gniewne rimbaudowskie wizje i skargi spadały na mnie i przyjaciół jak lawina górskiej wyprawy donikąd. ${ }^{13}$

12 "Not knowing about it I descended underground/It was like over-ground, only the light was different. Descending/I didn't expect it to happen so quickly/I thought/I have just buried my masters and I have/become my own master. [...]Shadows of inconsolable heritage of the world/passed by me as mists covered/ in thick layers."

13 "When you fall asleep together with a Kwidzyń sky from under a sheepskin coat/the light of our youth alights, which nobody wanted to protect./Your visions which were then angry in the manner of Rimbaud and grievances fell/on me and our friends as an avalanche of a mountain expedition to nowhere." 
A. NOWACZEWSKI, "THE MESSAGE OF THE CASTAWAY...”

Kornhauser admits that he and Karasek were on different roads. The best way to summarize their poetic choices is to use a typology created by Tadeusz Różewicz in "Opowiadanie dydaktyczne" ("A Didactic Short Story") - the division into poets of rubbish dumps and poets of clouds. The former was a poet of rubbish dumps, as he wanted to be closer to objects, things elementary and concrete, he refrained from visions; the latter ran away from the triviality of everyday life and he lived thanks to poets' words, he was a poet of clouds, he wanted to find, above clouds, a vision of the 'wholeness' of the world, a map of mythical continent, which is the whole. ${ }^{14}$ Kornhauser, as a mature poet, finally understood his friend's dreams, and after many years he paid homage to Karasek's disagreement with the loss of 'wholeness' and his search for it. Maybe it was the very vision of a continent above the sky which caught Kornhauser's imagination, even though Kornhauser as a poet looks downwards, to the earth and its details, looks to fragments of the microcosm. Gondwana, a few hundred million years ago, joined together South America, Africa, India and Australia. Gondwana annulled the oceans of today, existing in the place between these lands, but it also connected what is hottest, fullest with what is coldest. Gondwana harmoniously joins the opposites of the later periods. This is the paradise of the castaway.

Karasek answered Kornhauser with a text dedicated to him "Orpheus redivivus (Julianowi Kornhauserowi z orfickim pozdrowieniem)" (“Orpheus Redivisus (To Julian Kornhauser with Orphic Greetings")). He wrote in it that there is no recipe for a happy

\footnotetext{
${ }^{14}$ Grzegorz Kociuba saw it somewhat differently. According to him, Karasek is poeta furiosus, while Kornhauser is a contemplative poet. In this perspective, Karasek appears as a poet full of passions, inspirations; someone who believes that he is dependent on a force bigger than himself. He represents cognitive maximalism, distrust towards the tradition of a 'contemplative poet', while the contemplative poet dreams of unity between a word and a thing, a language and the world. See Grzegorz Kociuba, Ciemna kantyczka i blask szarości, in Było nie minęło. Antologia tekstów krytycznych poświęconych twórczości Juliana Kornhausera, ed. by Adrian Gleń, Opole 2011, 23-28.
} 
life, and that there is no one correct way of living. We have no control over our fate; it just happens to us:

Kto płacze we mnie? Kto się we mnie śmieje?

Życie jest jak wróbel w garści,

trzymasz za mocno, udusisz,

trzymasz za słabo, odleci.

Życie to zwykły

gorący sen. ${ }^{15}$

According to Grzegorz Kociuba, who interpreted this poem, Orpheus here is one of the archetypes of a writer, and his presence directs us to a type of inspired poet, a passionate one, who explores the multidimensionality of human fate perceived in his life and works. ${ }^{16}$

For Karasek, an important point of reference is the poetry of Dylan Thomas. In his Orhpic poems Karasek glorifies the vital forces directed vertically. Many times he referred to a famous poem by Thomas which opens with the phrase: "The force which through the green fuse drives the flower". Also metaphors combining opposites, as the "wintry fever' from this poem, are frequent in Karasek's poems. His poetry, seemingly intellectual and made of paper, is filled with life energy. Turns of imagination, the surrealistic daring of images, spectacular juxtapositions-these are all examples of the life energy Karasek is full of in his poems. His poetic vision is the result of a surplus; the power of words depends on the person who utters them. Karasek's readers often cannot understand these poems, as they are written against the correctness of the poetics dominant in the period. This correctness is determined, on the one hand, by the colloquial blank verse of Różewicz, devoid of Baroque elements, and on the other by the late poems of Czesław Miłosz, with its use of rhetoric. The poets

\footnotetext{
15 "Who cries in me? Who laughs in me?/Life is like a sparrow in the hand/you hold it too tight, you will/smother it/you hold too lightly/it will fly away/Life is an ordinary/hot dream."

${ }^{16}$ Kociuba, op. cit., 27.
} 
A. NOWACZEWSKI, “THE MESSAGE OF THE CASTAWAY...”

two generations younger than Karasek basically follow in the footsteps of two poetic dictions-of Andrzej Sosnowski and Roman Honet, while Karasek is strongly grounded in the tradition of the Polish avantgarde. He also remains faithful to the poetic fascinations of his youth, and this offers an explanation of his distance from the poetry of his generational colleagues-Adam Zagajewski and Ryszard Krynicki. Karasek is closer to Przyboś than to Miłosz, but it is Adam Ważyk and Zbigniew Herbert who are more important to him. His third master is a poet who today is unappreciated-Zbigniew Bieńkowski, with his predilection for writing long philosophical poems. This patronage blurs the reception of Karasek's poetry, because the type of Bieńkowski poetic today seems to be a cul-de-sac. How does Karasek put together in his poetry such distant inspirations?

It is possible thanks to a formula of poetry he has constructed for himself and which he presented perhaps most succinctly in the afterword to his volume Gondwana $i$ inne wiersze (Gondwana and Other Poems):

Poetry is making thinner, it is a discourse which is flattened, compacted [...]It is a discourse out of which 'boring' words are extracted, words with no meanings-the diluting water of narration. We live in the rarefied air of language. On the one hand, a not chaffed area of speech; on the other, poetry. ${ }^{17}$

Therefore, a poet may either succumb to colloquial language, which may lead to "melting in gab", ${ }^{18}$ or try sublimation, which, however, may result in the situation in which meanings are no longer clear and the language ambiguous. "Speech lowers a language, poetry uplifts it. Art is created through contrasts"19, wrote Karasek. He is a poet who takes risks and often gets close to both poles-both to 'gab' and to concentration on words. That may be the reason why today his reception is so meagre.

17 Krzysztof Karasek, Gondwana i inne wiersze, op. cit., 69-70.

${ }^{18}$ Ibid., 70.

19 Ibidem. 